\title{
Delineating management zones for precision agriculture applications: a case study on wheat in sub-tropical Brazil
}

\author{
Júnior Melo Damian, ${ }^{1}$ Osmar Henrique De Castro Pias, ${ }^{1}$ Antônio Luis Santi, ${ }^{1}$ \\ Nicola Di Virgilio, ${ }^{2}$ Juliano Berghetti, ${ }^{1}$ Lorenzo Barbanti, ${ }^{3}$ Roberta Martelli ${ }^{4}$ \\ ${ }^{1}$ Department of Agricultural and Environmental Sciences, Federal University of Santa Maria, RS, \\ Brazil; ${ }^{2}$ Institute of Biometeorology, National Research Council, Bologna, Italy; ${ }^{3}$ Department of \\ Agricultural Sciences, University of Bologna, Italy; ${ }^{4}$ Department of Agricultural and Food Sciences, \\ University of Bologna, Italy
}

\begin{abstract}
In sub-tropical Brazil, the wheat (Triticum aestivum L.) crop requires identification of pending constraints as premise for grain yield (GY) increases. In this light, spatial variation of soil properties and their relationship with GY were investigated in a case study, where the delineation of homogeneous zones could lead to site-specific management in view of crop improvement. In 2012, twelve chemical and physical soil attributes, GY and the three yield components (spikes per square meters, grains per spike, grain weight) were geo-referentially assessed in a $50 \times 50 \mathrm{~m}$ grid in a 4.7 ha wheat field. GY exhibited a modest mean $\left(2.61 \mathrm{Mg} \mathrm{ha}^{-1}\right)$, associated with a noticeable variation (CV, 17.4\%). A multiple stepwise regression of soil carbon (C) and $\mathrm{pH}$ explained a high share of $\mathrm{GY}$ variation $\left(\mathrm{R}^{2}, 0.83^{* *}\right)$. Maps of $\mathrm{C}$, $\mathrm{pH}$ and GY obtained through inverse distance weighting showed the spatial trends of the three traits. $\mathrm{C}$ and $\mathrm{pH}$ clustering delineated three homogeneous zones at respective low, intermediate and high levels of $\mathrm{C}, \mathrm{pH}$, and also GY, setting the premise for a differential management of crop inputs. In particular, a significant part (21.8\%) of field surface featured very low GY (2.05 $\mathrm{Mg} \mathrm{ha}^{-1}$ ); thus substantial yield increase could be envisaged through targeted supply of organic amendments (soil C, $14.1 \mathrm{~g} \mathrm{dm}^{-3}$ ), and especially lime (soil $\left.\mathrm{pH}, 4.92\right)$. A larger field portion (54\%) showed intermediate GY (2.65 $\left.\mathrm{Mg} \mathrm{ha}^{-1}\right), \mathrm{C}\left(15.3 \mathrm{~g} \mathrm{dm}^{-3}\right)$ and $\mathrm{pH}$ (5.23), deserving a lesser degree of amelioration. The remaining
\end{abstract}

Correspondence: Lorenzo Barbanti, Department of Agricultural Sciences, University of Bologna, via Zamboni 33, 40126 Bologna, Italy.

E-mail: lorenzo.barbanti@unibo.it

Key words: Grain yield; management zones; precision agriculture; soil properties; spatial variability; wheat.

Received for publication: 16 October 2015.

Revision received: 29 April 2016.

Accepted for publication: 30 April 2016.

(C) Copyright J.M. Damian et al., 2016

Licensee PAGEPress, Italy

Italian Journal of Agronomy 2016; 11:713

doi:10.4081/ija.2016.713

This article is distributed under the terms of the Creative Commons Attribution Noncommercial License (by-nc 4.0) which permits any noncommercial use, distribution, and reproduction in any medium, provided the original author(s) and source are credited.
$24.2 \%$ of field surface exhibited the highest GY (3.16 Mg ha-1), C (17.2 $\mathrm{g} \mathrm{dm}^{-3}$ ) and $\mathrm{pH}$ (5.46). Based on the difference between GY registered in the low vs. high zone, overcoming soil constraints could be credited with a remarkable ( $>50 \%$ ) yield increase, although further years of wheat cropping would be needed to prove the consistency of the two temporally stable soil traits, $\mathrm{C}$ and $\mathrm{pH}$, as yield determinants. Nevertheless, this case study addressing a world area that features very different conditions from wheat grown in temperate regions shows good prospects for variable application of crop inputs in the frame of precision agriculture techniques.

\section{Introduction}

Wheat (Triticum aestivum L.) is one of the main cereals at world level. It covers $27 \%$ of global cereal production (FAOSTAT, 2015), with nearly half of its surface and production taking place in developing countries (Singh and Trethowan, 2007). In Brazil, a wheat cultivation surface of 1.895 million ha with an average yield of $2.31 \mathrm{Mg} \mathrm{ha}^{-1}$ was recorded in the year 2013 (CONAB, 2014). This yield per hectare is considered low, compared to a world average of $3.27 \mathrm{Mg} \mathrm{ha}^{-1}$ registered in the same year (FAOSTAT, 2015). Thus, yield improvements are actively sought to overcome inherent constraints reflecting on the agricultural development of large areas. According to Zanon et al. (2012), increasing the knowledge of crop response to environmental factors and cultivation practices is a key point in the quest to improve wheat production in Brazil.

The yield potential of a crop is defined as the highest yield attained by a plant or plant community, depending on the constraints posed by some characteristics of the cultivation environment (Evans and Fischer, 1999). Based on this, increase in productivity involves a previous appraisal of the environmental factors influencing crop growth and efficiency in the use of internal (e.g., naturally available water) and external (e.g., nitrogen from fertiliser) resources of the system. Therefore, understanding the relationships among plant and soil factors responsible for yield fluctuations is a key point in the management of a wheat crop aimed for high productivity (Miranzadeh et al., 2011). Among the numerous factors influencing crop growth, soil chemical and physical attributes deserve special attention (Machraoui et al., 2010; Rasouli et al., 2013), and this is also the case of plant attributes concerning yield components (Chen et al., 2010).

One of the major challenges in crop systems is assessing the spatial homogeneity of the above-referred attributes. This should be coupled with the development of more efficient cultivation practices, in view of reducing environmental impact while concurrently enhancing crop profit (Moreno et al., 2013). To this aim, the adoption of preci- 
sion agriculture (PA) techniques is seen a valuable approach to combine plant and soil attributes in a joint analysis of their spatial variation in wheat (Diacono et al., 2013). In this frame, Pearson's correlation is one of the simplest and most widely used tools to match soil characteristics with plant traits (Miao et al., 2006). Multiple regressions represent a further step, combining parameters to explain a higher share of a trait's variation.

The application of PA techniques involves the delineation of homogeneous zones, as regards soil chemical and physical characteristics influencing crop growth and yield. This is a pre-requisite for the implementation of a differential supply of crop inputs (e.g., fertilisers and amendments), according to each zone's potential and estimated requirements. This approach is expected to enhance the efficiency in cropping while restraining its costs and environmental impact (Pierce and Nowak, 1999; Stafford et al., 1999).

Given the pending problem of low agricultural production in many world areas, and in light of the stimulating prospects for PA diffusion, this case study addressed the spatial variation of soil chemical and physical characteristics and their influence on wheat yield parameters. The study was carried out in a 4.7 ha wheat field in an area of sub-tropical Brazil where the problem is particularly severe. Specific objects were to: i) discover yield-limiting factors among soil parameters; ii) show the spatial variability of soil attributes associated with crop productivity; iii) delineate differential management zones as exploratory technique indicating which part of the field is potentially most responsive to amelioration through site specific management of crop inputs.

\section{Materials and methods}

\section{Experimental field}

The study was conducted in 2012 , in a 4.7 ha experimental field located in Palmeira das Missões (27 52 ' 48 “ S, $53^{\circ}$ 9' 43” W; ca. 600 $\mathrm{m}$ a.s.l.), Rio Grande do Sul, Brazil. The land is gently undulating and the soil is classified as Dystrofic Red Latisol (Santos et al., 2013). The crop was managed through a consolidated no-tillage seeding system. Climate is very wet sub-tropical, with $18.1^{\circ} \mathrm{C}$ mean temperature and $1919 \mathrm{~mm}$ total precipitation (Maluf, 2000). Daily temperatures and precipitation were registered during the experiment at a local meteorological station.

Wheat (T. aestivum L.), cv. Quartzo (OR Sementes, Passo Fundo, RS, Brazil), was sown on June 14, 2012, with 330 seeds $\mathrm{m}^{-2}$ at $0.2 \mathrm{~m}$ row spacing. The field had previously been double cropped with wheat followed by soybean. Prior to seeding, NPK fertiliser (15-20-30) was applied at $250 \mathrm{~kg} \mathrm{ha}^{-1}$; at the three leaf stage, urea $(45 \% \mathrm{~N})$ was applied at $150 \mathrm{~kg} \mathrm{ha}^{-1}$. Other crop practices were carried out following the guidelines for the wheat crop in the area.

\section{Soil sampling design}

The boundaries of the experimental field were geo-localised through a Garmin ${ }^{\circledR}$ Legend (Garmin International, Inc., Olathe, KS, USA) GPS. A sampling grid was established with $50 \times 50 \mathrm{~m}(0.25 \mathrm{ha})$ cell size through the CR-Campeiro 7 software (Giotto and Robaina, 2007), which interpolates for each pixel a central coordinate based on grid size, producing a total of 18 sampling points. These points were detected and recorded via the GPS Garmin® Legend.

\section{Soil and crop properties}

Before sowing, soil sampling for chemical analysis was carried out in the 18 geo-referenced points with a manual auger, taking 10 cores at the $0-0.15 \mathrm{~m}$ depth in a $10 \mathrm{~m}$ radius around each point. The following chemical traits were determined, based on established procedures (Tedesco et al., 1995): $\mathrm{pH}$ (in $\mathrm{H}_{2} \mathrm{O}$ at 1:1); exchangeable acidity ( $\mathrm{H}+\mathrm{Al}$ ) and cation exchange capacity (CEC); exchangeable calcium (Ca), magnesium $(\mathrm{Mg})$ and potassium $(\mathrm{K})$ and their ratios; organic carbon $(\mathrm{C})$, total Kjeldahl nitrogen $(\mathrm{N})$ and their ratio $(\mathrm{C} / \mathrm{N})$; available phosphorus (P). Concentrations were expressed per unit soil volume. Data interpretation was based on the thresholds established at a local scale (CQFS, 2004).

At the same time, soil sampling for physical attributes was carried out in the 18 geo-referenced points taking three cores of undisturbed soil $\left(7.81 \mathrm{~cm}^{-3}\right.$ cylinders $)$ at three depths (0-0.05, 0.05-0.10 and 0.10$0.15 \mathrm{~m}$ ). Soil physical traits included bulk density (BD) and porosity, based on the methods described by EMBRAPA (2006), and soil strength (SS). BD was determined as the ratio between dry weight $\left(105^{\circ} \mathrm{C}\right)$ and volume of undisturbed soil. Total porosity was determined by comparing water saturated $\left(48 \mathrm{~h}\right.$ hydration) with dry $\left(105^{\circ} \mathrm{C}\right)$ soil weight. Micro-porosity was assessed after water saturation by applying a suction force of $6 \mathrm{kPa}$ for $48 \mathrm{~h}$ : data of soil weight at saturation, after equilibrium at $6 \mathrm{kPa}$ and after drying $\left(105^{\circ} \mathrm{C}\right)$, were used to calculate microporosity. Macro-porosity was calculated as the difference between total and micro-porosity. SS, i.e., soil resistance to penetration, was measured in the same soil layers as the other physical traits $(0-0.5,0.05$ 0.10 and $0.10-0.15 \mathrm{~m}$ ), using the portable digital penetrometer PenetroLOG® PLG1020 (Falker Agricultural Automation, Porto Alegre, RS, Brazil). Each measurement was the average of 15 readings in a 3 $\mathrm{m}$ radius around the sampling point.

Crop yield parameters were determined at plant maturity (October 29, 2012), harvesting by hand three $1 \mathrm{~m}^{2}$ plots around each sampling point. Yield parameters included grain yield (GY; $\mathrm{Mg} \mathrm{ha}^{-1}$ ) and its three components: spike density ( $\mathrm{S} / \mathrm{m}^{2} ;$ no. $\left.\mathrm{m}^{-2}\right)$, grains per spike (G/S; no. spike $^{-1}$ ), and mean grain weight (MGW; mg).

\section{Data analysis}

\section{Exploratory statistical analysis}

Descriptive statistics of soil and crop parameters in the 18 geo-referenced points included mean, median, minimum, maximum, standard deviation, coefficient of variation (CV), skewness and kurtosis. Normal distribution of data was ascertained through the Kolmogorov-Smirnov test. Pearson's correlation (r) between soil and plant traits was assessed in order to evaluate the degree of inter-relationship, and multiple linear regressions (stepwise forward procedure) was used to evaluate the ability of soil traits to explain GY variation. Analyses were performed with the Statistica 10 software (StatSoft Corp., Tulsa, OK, USA).

\section{Geostatistics, spatial structure and map creation}

Thematic maps of yield and soil characteristics were produced using the inverse distance weighting (IDW) interpolation method. IDW assumes that each point value has a local influence that decreases with distance (Bonham-Carter, 1994). Despite a limited number of data points (18), the ordinary kriging $(\mathrm{OK})$ procedure was also carried out as an attempt to describe the spatial variability of traits, via the modelisation of semivariance and semivariograms characterising the spatial variation set against the distance (lag distance) (Cambardella and Karlen, 1999). QuantumGIS (OSGeo), an open source GIS software, was used to produce maps, while an ArcView GIS (ESRI, Redlands, CA, USA) script (Kriging interpolator 3.2), representing a full implementation of the kriging commands in avenue language, was used to model semivariograms.

\section{Management zones}

Sub-division of the experimental field into homogeneous manage- 
ment zones, i.e., featuring low intra-zonal vs. high inter-zonal variation, was carried out to delineate areas suited for a differential intensity of ameliorating practices. Soil parameters shown by the stepwise regression to significantly explain GY variation were subjected to clustering through the generalised k-means clustering algorithm (Hartigan and Wong, 1978) of the Statistica 10 software (StatSoft Corp.), using Euclidean distances of data points from cluster centres. The optimal number of clusters for creating management zones was based on minimisation of normalised classification entropy, as described by Fridgen et al. (2004). Data of soil traits and yield parameters observed in the delineated clusters were submitted to a one-way analysis of variance. The least significant difference at $\mathrm{P} \leq 0.05$ was used to separate means of significant traits. Thereafter, a map of clustered points was produced through ordinary kriging, as in the case of single soil traits.

\section{Results and discussion}

\section{Weather conditions during the experiment}

Weather conditions during wheat growth (Figure 1) reflected the very wet sub-tropical climate of the area (Maluf, 2000): a total of 877 $\mathrm{mm}$ was received in the five months June-October $2012 \mathrm{vs}$ a long term average of $871 \mathrm{~mm}$. Despite some difference in rainfall distribution between 2012 and the mean pattern, moisture could hardly be considered a limiting factor to wheat growth in 2012.

\section{Descriptive statistics of soil and crop traits}

Soil properties exhibited a remarkable variation in physical and chemical traits within the 4.7 ha field. In physical traits (Table 1), macro-porosity was always below the critical threshold of $0.1 \mathrm{~m}^{3} \mathrm{~m}^{-3}$ (Taylor et al., 1966), and represented a modest share of total porosity (average, 12\%). The low macro-porosity and its decrease with depth was consistent with abundance of caolin and $\mathrm{Fe}+\mathrm{Al}$ oxides that are typical of Latisols, leading to a dense plasma especially in deep layers (Suzuki et al., 2008). Macro-porosity was associated with a strong spatial variation in all layers and their average (CV's between 28 and 50\%). Compared to macro-porosity, micro-porosity showed much higher mean data (always above $0.35 \mathrm{~m}^{3} \mathrm{~m}^{-3}$ ), associated with a low variation (CV's $<5 \%$ ). BD was consistently around $1.3 \mathrm{~kg} \mathrm{dm}^{-3}$ at all depths in the whole field (CV's $<10 \%)$. Lastly, SS displayed a two-fold increase in mean data from shallow $(0-0.05 \mathrm{~m})$ to intermediate layer $(0.05-0.10 \mathrm{~m})$, and a further $25 \%$ increase from intermediate to deep layer (0.10-0.15 $\mathrm{m}$ ). In SS, spatial variation declined with depth (CV from 34 to $9 \%$ ), i.e. soil firmness in the deep layer was more consistent than soil softness in the shallow layer. The inconsistency of SS data at the 0-0.05 m depth could be associated with no tillage practices enhancing the heterogeneity in this layer determined by field traffic, seeding organs, etc.

The complexity of physical traits outlined a soil with good physical properties, with the partial exception of a low macro-porosity that could limit soil roominess for plant roots and other biota. However, the steep increase of SS in depth was not accompanied by a similar trend of BD, in contrast to other sources (Ehlers et al., 1983; Taylor et al., 1966). This could be due to no-till management leading to stronger soil aggregates, but exerting a modest effect on porosity and BD.

Modest correlations were observed in the four traits between shallow and deep layer ( $\mathrm{r}$ between 0.26 and 0.34 ; data not shown). Based on this, only the average data, i.e. those representing the 0-0.15 m layer, were retained in subsequent analysis.

Chemical traits assessed in the 0-0.15 m layer trace a multi-faceted picture of soil characteristics (Table 2). The soil was definitely acid

Table 1. Descriptive statistics of soil physical properties in three soil layers and their average.

\begin{tabular}{|c|c|c|c|c|c|c|c|c|c|}
\hline Trait & Mean & Median & Min & $\operatorname{Max}$ & SD & CV & Skewness & Kurtosis & K-S \\
\hline \multicolumn{10}{|c|}{ 0.00-0.05 m depth } \\
\hline $\operatorname{MaP}\left(\mathrm{m}^{3} \mathrm{~m}^{-3}\right)$ & 0.064 & 0.063 & 0.015 & 0.137 & 0.032 & 50.0 & 0.36 & 0.30 & ns \\
\hline $\operatorname{MiP}\left(\mathrm{m}^{3} \mathrm{~m}^{-3}\right)$ & 0.380 & 0.386 & 0.328 & 0.408 & 0.018 & 4.7 & -1.69 & 4.53 & ns \\
\hline $\mathrm{BD}\left(\mathrm{kg} \mathrm{dm}^{-3}\right)$ & 1.28 & 1.27 & 0.97 & 1.41 & 0.11 & 8.7 & -1.19 & 2.40 & ns \\
\hline $\mathrm{SS}(\mathrm{kPa})$ & 726 & 683 & 292 & 1107 & 246 & 33.9 & -0.04 & -0.77 & ns \\
\hline \multicolumn{10}{|c|}{ 0.05-0.10 m depth } \\
\hline $\mathrm{MaP}\left(\mathrm{m}^{3} \mathrm{~m}^{-3}\right)$ & 0.054 & 0.053 & 0.030 & 0.094 & 0.018 & 33.5 & 0.83 & 0.32 & ns \\
\hline $\operatorname{MiP}\left(\mathrm{m}^{3} \mathrm{~m}^{-3}\right)$ & 0.390 & 0.392 & 0.375 & 0.410 & 0.010 & 2.7 & 0.21 & -1.06 & ns \\
\hline $\mathrm{BD}\left(\mathrm{kg} \mathrm{dm}^{-3}\right)$ & 1.33 & 1.34 & 1.26 & 1.38 & 0.04 & 2.7 & -0.56 & -0.78 & ns \\
\hline $\mathrm{SS}(\mathrm{kPa})$ & 2125 & 2102 & 1645 & 2777 & 314 & 14.8 & 0.57 & -0.23 & ns \\
\hline \multicolumn{10}{|c|}{ 0.10-0.15 m depth } \\
\hline $\operatorname{MaP}\left(\mathrm{m}^{3} \mathrm{~m}^{-3}\right)$ & 0.046 & 0.045 & 0.024 & 0.079 & 0.014 & 31.3 & 1.07 & 1.32 & ns \\
\hline $\operatorname{MiP}\left(m^{3} m^{-3}\right)$ & 0.388 & 0.392 & 0.356 & 0.401 & 0.011 & 2.8 & -1.61 & 3.15 & ns \\
\hline $\mathrm{BD}\left(\mathrm{kg} \mathrm{dm}^{-3}\right)$ & 1.32 & 1.32 & 1.24 & 1.43 & 0.05 & 3.6 & 0.61 & 0.54 & ns \\
\hline $\mathrm{SS}(\mathrm{kPa})$ & 2636 & 2613 & 2276 & 3047 & 228 & 8.6 & 0.19 & -0.95 & ns \\
\hline \multicolumn{10}{|c|}{ Average } \\
\hline $\operatorname{MaP}\left(\mathrm{m}^{3} \mathrm{~m}^{-3}\right)$ & 0.055 & 0.056 & 0.024 & 0.088 & 0.015 & 27.8 & -0.01 & 0.70 & ns \\
\hline $\operatorname{MiP}\left(m^{3} m^{-3}\right)$ & 0.387 & 0.389 & 0.366 & 0.399 & 0.009 & 2.4 & -0.69 & -0.12 & ns \\
\hline $\mathrm{BD}\left(\mathrm{kg} \mathrm{dm}^{-3}\right)$ & 1.31 & 1.32 & 1.18 & 1.37 & 0.05 & 3.6 & -1.05 & 1.50 & ns \\
\hline $\mathrm{SS}(\mathrm{kPa})$ & 1829 & 1805 & 1436 & 2276 & 231 & 12.6 & 0.40 & -0.40 & ns \\
\hline
\end{tabular}

SD, standard deviation; CV, coefficient of variation; K-S, significance at the Kolmogorov-Smirnov test for normal distribution; ns, not significant; MaP, macro-porosity; MiP, micro-porosity; BD, bulk density; SS, soil strength. 
with maximum pH 5.6. Mean organic carbon was $15.5 \mathrm{~g} \mathrm{dm}^{-3}$, corresponding to $26.7 \mathrm{~g} \mathrm{dm}^{-3}$ organic matter, i.e., $\sim 20 \mathrm{~g} \mathrm{~kg}^{-1}$ at a $1.3 \mathrm{~kg} \mathrm{dm}^{-3}$ of BD: this is a relatively low level of organic matter for many crops (Jones, 2003), although it is quite normal for soils under warm, moist climate (Brady and Weil, 2008). Total Kjeldahl nitrogen was well balanced with organic carbon, as shown by a $\mathrm{C} / \mathrm{N}$ ratio close to 10 . Mean $\mathrm{P}$ was below the critical level of $12 \mathrm{mg} \mathrm{m}^{-3}$, based on the thresholds adopted for the specific extraction method (Mehlich-1) (CQFS, 2004). However, only a small portion of the field $(<20 \%)$ was actually deficient in this nutrient $\left(<8 \mathrm{mg} \mathrm{m}^{-3}\right)$. Compared to this, exchangeable $\mathrm{K}$ was always at a good level (CQFS, 2004). CEC was quite normal, although exchangeable bases barely constituted 50\% of CEC (data not shown), given the weight of $\mathrm{H}+\mathrm{Al}$ that are responsible for strong acidity in many sub-tropical soils. $\mathrm{Ca} / \mathrm{Mg}$ and $\mathrm{Mg} / \mathrm{K}$ ratios showed a relatively high $\mathrm{Mg}$ content, reflecting in low $\mathrm{Ca} / \mathrm{Mg}$ and high $\mathrm{Mg} / \mathrm{K}$, in the average (CQFS, 2004). Santi et al. (2012) found that especially the $\mathrm{Ca} / \mathrm{Mg}$ ratio may be a limiting factor, a circumstance that should be considered when planning fertiliser practices for high wheat yield. The descriptive statistics of crop yield parameters (Table 3 ) showed that the average grain yield per hectare passed the State's (1.94 $\mathrm{Mg} \mathrm{ha}^{-1}$ ) and Country's average for the same year (2.31 Mg ha-1), indicating favourable growth conditions (CONAB, 2014), while remaining at low level on a world scale (FAOSTAT, 2015). GY exhibited a higher variation (CV, 17.4\%) than the three yield components (CV's from 4.1 to 10.4\%). This means that their variations were not counterbalanced in the comprehensive trait (GY). The noticeable variation associated with GY represents a potential for varying crop management within the field, in view of improving low yielding areas.

\section{Relationships in soil and crop data}

Several significant correlations were found between soil and crop parameters (Table 4). In soil traits, the negative correlation between macro- and micro-porosity $\left(\mathrm{r}=-0.58^{* *}\right)$, and especially between macroporosity and $\mathrm{BD}\left(\mathrm{r}=-0.82^{* *}\right)$, highlight the reciprocal relationships among physical properties (Brady and Weil, 2008). Conversely, SS that exhibited the largest variation in depth was not correlated with the rest of physical traits. In crop parameters, good correlations were obviously found between $\mathrm{GY}$ and the three yield components ( $\mathrm{r}$ between $0.62^{* *}$ and $0.79^{* *}$ ). GY was substantially unrelated to physical traits, whereas it was found to be positively related to $\mathrm{C}, \mathrm{pH}$ and $\mathrm{C} / \mathrm{N}\left(\mathrm{r}=0.73^{* *}, 0.71^{* *}\right.$ and $0.69^{* *}$ in the three respective cases). The three yield components,

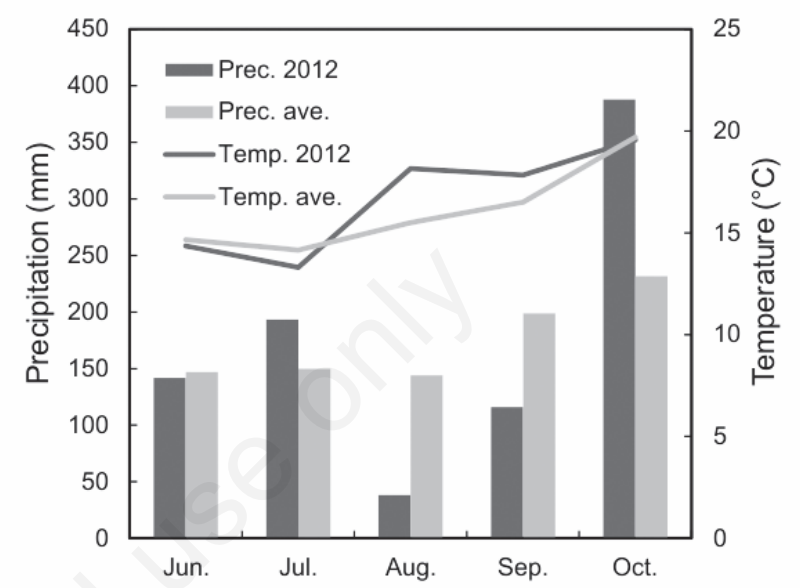

Figure 1. Pattern of precipitation and temperature during the experiment (June-October 2012) and long term average for the same months.

Table 2. Descriptive statistics of soil chemical properties in the 0-0.15 m layer.

\begin{tabular}{|c|c|c|c|c|c|c|c|c|c|}
\hline Trait & Mean & Median & Min & $\operatorname{Max}$ & SD & $\mathrm{CV}$ & Skewness & Kurtosis & $\mathrm{K}-\mathrm{S}$ \\
\hline $\mathrm{pH}$ & 5.21 & 5.30 & 4.60 & 5.60 & 0.28 & 5.5 & -0.48 & -0.60 & ns \\
\hline $\mathrm{C}\left(\mathrm{g} \mathrm{dm}^{-3}\right)$ & 15.5 & 15.2 & 13.1 & 20.2 & 1.9 & 12.2 & 1.04 & 1.09 & ns \\
\hline$N\left(g^{-3}\right)$ & 1.73 & 1.75 & 1.40 & 2.00 & 0.18 & 10.5 & -0.16 & -1.08 & ns \\
\hline $\mathrm{C} / \mathrm{N}$ & 9.0 & 9.0 & 7.0 & 11.4 & 1.1 & 11.9 & 0.23 & 0.59 & ns \\
\hline $\mathrm{P}\left(\mathrm{mg} \mathrm{dm}^{-3}\right)$ & 11.3 & 10.9 & 5.8 & 15.4 & 2.9 & 25.8 & -0.52 & -0.32 & ns \\
\hline $\mathrm{K}\left(\mathrm{mg} \mathrm{dm^{-3 }}\right)$ & 156 & 153 & 105 & 215 & 37 & 23.4 & 0.39 & -1.00 & ns \\
\hline $\mathrm{H}+\mathrm{Al}\left(\mathrm{cmolc}^{+} \mathrm{dm}^{-3}\right)$ & 6.9 & 6.2 & 4.4 & 13.8 & 2.4 & 34.4 & 1.70 & 3.15 & ns \\
\hline $\mathrm{Ca}\left(\mathrm{cmol}_{\mathrm{c}}^{+} \mathrm{dm}^{-3}\right)$ & 4.6 & 4.6 & 2.5 & 6.0 & 0.9 & 19.7 & -0.74 & 0.70 & ns \\
\hline $\operatorname{Mg}\left(\mathrm{cmol}_{c}{ }^{+} \mathrm{dm}^{-3}\right)$ & 2.2 & 2.1 & 1.0 & 2.9 & 0.5 & 24.3 & -0.58 & 0.03 & ns \\
\hline $\mathrm{CEC}\left(\mathrm{cmol}_{\mathrm{c}}{ }^{+} \mathrm{dm}^{-3}\right)$ & 14.0 & 13.8 & 9.5 & 22.4 & 3.3 & 23.4 & 1.06 & 1.49 & ns \\
\hline $\mathrm{Ca} / \mathrm{Mg}$ & 2.1 & 2.0 & 1.8 & 2.5 & 0.2 & 9.5 & 0.53 & 0.34 & ns \\
\hline $\mathrm{Mg} / \mathrm{K}$ & 5.6 & 5.9 & 3.1 & 8.1 & 1.6 & 29.1 & -0.19 & -1.31 & ns \\
\hline
\end{tabular}

$\mathrm{SD}$, standard deviation; CV, coefficient of variation; K-S, significance at the Kolmogorov-Smirnov test for normal distribution; ns, not significant; C, carbon; N, nitrogen; P, phosphorus; K, potassium; $\mathrm{H}+\mathrm{Al}$, exchangeable acidity; Ca, calcium; Mg, magnesium; CEC, cation exchange capacity.

Table 3. Descriptive statistics of crop yield parameters.

\begin{tabular}{|c|c|c|c|c|c|c|c|c|c|}
\hline Trait & Mean & Median & Min & Max & SD & CV & Skewness & Kurtosis & K-S \\
\hline $\mathrm{S} / \mathrm{m}^{2}\left(\right.$ no. $\left.\mathrm{m}^{-2}\right)$ & 332 & 332 & 260 & 378 & 35 & 10.4 & -0.44 & -0.64 & ns \\
\hline G/S (no. spike ${ }^{-1}$ ) & 30.2 & 30.6 & 24.8 & 34.6 & 2.7 & 8.8 & -0.28 & -0.61 & ns \\
\hline MGW (mg) & 25.9 & 26.0 & 23.6 & 27.9 & 1.1 & 4.1 & -0.45 & 0.14 & ns \\
\hline GY $\left(\mathrm{Mg} \mathrm{ha}^{-1}\right)$ & 2.61 & 2.61 & 1.88 & 3.44 & 0.45 & 17.4 & -0.09 & -0.63 & ns \\
\hline
\end{tabular}

SD, standard deviation; CV, coefficient of variation; K-S, significance at the Kolmogorov-Smirnov test for normal distribution; S/m², no. of spikes per square meter; ns, not significant; G/S, no. of grains per spike; MGW, mean grain weight; GY, grain yield per hectare. 
with the partial exception of MGM, were also quite well correlated with $\mathrm{C}, \mathrm{pH}$ and $\mathrm{C} / \mathrm{N}$ (Table 4).

The stepwise regression of soil physical and chemical traits on GY produced the following equation:

$\mathrm{GY}=-4.257+0.140 * \mathrm{C}+0.904 * \mathrm{pH} ; \mathrm{R}^{2}=0.83^{* *}$

Hence, the two traits showing the best simple relations with GY also exerted a combined effect in a multiple equation explaining $83 \%$ of grain yields variation.

In the literature, studies on wheat GY as dependent on soil physical traits addressed hydraulic properties of soils featuring high clay (Hakojärvi et al., 2013) or sodium content (Rasouli et al., 2013). However, also in those cases correlations of GY with physical traits were not consistent. Conversely, inverse correlation of GY with sodium content, in turn associated with very high $\mathrm{pH}$, was good in the work of Rasouli et al. (2013). Thereby, it is evinced that very anomalous pH values as in the cited source (up to 9.1) and the present study (down to 4.6), represent a constraint the wheat crop is very sensitive to. Hence, benefits from $\mathrm{pH}$ correction by means of appropriate amendments are most likely incurred. Compared to this, the beneficial role of $\mathrm{C}$, despite a non-negligible soil status ( $\mathrm{C}$ min., $13.1 \mathrm{~g} \mathrm{dm}^{-3}$ ), may be explained with the positive role played by organic matter in alleviating the effects of soil acidity (pH) and toxicity ( $\mathrm{Al})$. Nevertheless, soil $\mathrm{pH}$ and $\mathrm{C}$ were reciprocally independent in our experiment, as shown by their low correlation (Table 4).

\section{Spatial distribution of soil and crop data}

Continuous maps of the two soil traits and the four yield parameters produced through IDW interpolation are shows in Figure 2 and 3, respectively. Soil C (Figure 2A) showed an eastward trend of increasing values. Compared to this, $\mathrm{pH}$ (Figure 2B) outlined a modest range of variation, with highest values in the central - south position. In grain yield parameters (Figure 3), general eastward trends of data increase can be observed.

Despite a limited number of data points (18), maps produced with OK (not shown) were consistent with those obtained through IDW. OK involves the assessment of indicators from semivariograms, i.e., nugget, sill, range and random variation (Table 5), allowing the spatial structure to be properly described.

Lag distance ranged from 15 to $50 \mathrm{~m}$. Best fitting models for actual semivariograms (not shown) were Gaussian for $\mathrm{C}$ and $\mathrm{pH}$, circular for

Table 4. Pearson's correlations between soil and crop yield parameters.

\begin{tabular}{|c|c|c|c|c|c|c|c|c|c|c|c|c|c|c|c|c|c|c|c|}
\hline & MaP ave. & MiP ave. & BD ave. & SS ave. & $\mathrm{pH}$ & C & $\mathrm{N}$ & $\mathrm{C} / \mathbb{N}$ & P & K & $\mathrm{H}+\mathrm{Al}$ & $\mathrm{Ca}$ & $\mathrm{Mg}$ & $\mathrm{CEC}$ & $\mathrm{Ca} / \mathrm{Mg}$ & $\mathrm{Mg} / \mathrm{K}$ & $\mathrm{S} / \mathrm{m}^{2}$ & G/S & MGW \\
\hline MiP ave. & $-0.58 * *$ & - & - & - & - & - & - & - & - & - & - & - & - & - & - & - & - & - & - \\
\hline BD ave. & $-0.82^{* *}$ & $0.53^{*}$ & - & - & - & - & - & - & - & - & - & - & - & - & - & - & - & - & - \\
\hline SS ave. & -0.01 & 0.15 & -0.24 & - & - & - & - & - & - & - & - & - & - & - & - & - & - & - & - \\
\hline $\mathrm{pH}$ & 0.05 & 0.13 & 0.09 & 0.35 & - & - & - & - & - & - & - & - & - & - & - & - & - & - & - \\
\hline$C$ & $0.52 *$ & -0.16 & $-0.65 * *$ & 0.28 & 0.26 & - & - & - & - & - & - & - & - & - & - & - & - & - & - \\
\hline $\mathrm{N}$ & $0.63^{* *}$ & -0.09 & $-0.72^{* *}$ & 0.20 & -0.13 & $0.51^{*}$ & - & - & - & - & - & - & - & - & - & - & - & - & - \\
\hline $\mathrm{C} / \mathrm{N}$ & -0.14 & -0.03 & 0.02 & 0.20 & 0.37 & $0.56^{*}$ & -0.40 & - & - & - & - & - & - & - & - & - & - & - & - \\
\hline P & -0.09 & -0.02 & -0.01 & 0.18 & -0.07 & 0.23 & 0.14 & 0.12 & - & - & - & - & - & - & - & - & - & - & - \\
\hline $\mathrm{K}$ & 0.04 & -0.25 & -0.06 & -0.05 & -0.01 & 0.12 & -0.17 & 0.28 & 0.36 & - & - & - & - & - & - & - & - & - & - \\
\hline $\mathrm{H}+\mathrm{Al}$ & -0.39 & 0.29 & $0.52^{*}$ & -0.09 & 0.35 & -0.24 & -0.35 & 0.07 & 0.18 & -0.01 & - & - & - & - & - & - & - & - & - \\
\hline $\mathrm{Ca}$ & -0.10 & 0.18 & 0.35 & 0.05 & $0.66^{* *}$ & -0.17 & -0.25 & 0.04 & -0.06 & 0.39 & 0.42 & - & - & - & - & - & - & - & - \\
\hline $\mathrm{Mg}$ & -0.16 & 0.22 & 0.37 & 0.08 & $0.76^{* *}$ & -0.17 & -0.25 & 0.05 & -0.14 & 0.19 & $0.48 *$ & $0.95^{* *}$ & - & - & - & - & - & - & - \\
\hline CEC & -0.33 & 0.29 & $0.53^{*}$ & -0.04 & $0.56 *$ & -0.25 & -0.37 & 0.08 & 0.10 & 0.16 & $0.92 * *$ & $0.74^{* *}$ & $0.78^{* *}$ & - & - & - & - & - & - \\
\hline $\mathrm{Ca} / \mathrm{Mg}$ & 0.11 & -0.10 & -0.17 & -0.21 & $-0.72^{* *}$ & 0.05 & 0.13 & -0.12 & 0.26 & 0.25 & -0.31 & $-0.51^{*}$ & $-0.74^{* *}$ & $-0.48 *$ & - & - & - & - & - \\
\hline $\mathrm{Mg} / \mathrm{K}$ & -0.11 & 0.31 & 0.32 & 0.09 & $0.62^{* *}$ & -0.20 & -0.06 & -0.15 & -0.35 & $-0.56^{*}$ & 0.34 & $0.50^{*}$ & $0.69^{* *}$ & $0.48^{*}$ & $-0.80 * *$ & - & - & - & - \\
\hline $\mathrm{S} / \mathrm{m}^{2}$ & 0.29 & 0.05 & -0.28 & 0.10 & $0.51^{*}$ & $0.70^{* *}$ & 0.21 & $0.51^{*}$ & 0.02 & -0.03 & 0.21 & 0.14 & 0.19 & 0.22 & -0.21 & 0.20 & - & - & - \\
\hline G/S & 0.00 & 0.12 & -0.08 & 0.28 & $0.65^{* *}$ & $0.49 *$ & -0.08 & $0.59 * *$ & 0.14 & -0.05 & -0.01 & 0.09 & 0.20 & 0.05 & -0.39 & 0.18 & 0.29 & - & - \\
\hline MGW & 0.11 & $-0.47^{*}$ & -0.08 & -0.04 & 0.43 & 0.27 & -0.28 & $0.50^{*}$ & 0.16 & 0.00 & 0.15 & 0.02 & 0.14 & 0.14 & -0.37 & 0.15 & 0.30 & $0.46^{*}$ & - \\
\hline GY & 0.22 & -0.04 & -0.25 & 0.21 & $0.71^{* *}$ & $0.73^{* *}$ & 0.05 & $0.69 * *$ & 0.10 & -0.06 & 0.12 & 0.10 & 0.22 & 0.15 & -0.42 & 0.24 & $0.79 * *$ & $0.78^{* *}$ & $0.62 * *$ \\
\hline
\end{tabular}

MaP, macro-porosity; ave., averge; MiP, micro-porosity; BD, bulk density; SS, soil strength; C, carbon; N, nitrogen; P, phosphorus; K, potassium; H+Al, exchangeable acidity; Ca, calcium; Mg, magnesium; CEC, cation exchange capacity; $\mathrm{S} / \mathrm{m}^{2}$, no. of spikes per square meter; $\mathrm{G} / \mathrm{S}$, no. of grains per spike; MGW, mean grain weight $(\mathrm{mg}) ; \mathrm{GY}$, grain yield per hectare $\left(\mathrm{Mg}^{-1}\right)$. $r$ values significant at $* \mathrm{P} \leq 0.05$ and $* * \mathrm{P} \leq 0.01$, respectively $(\mathrm{n}=18)$.

Table 5. Semivariogram models and spatial distribution parameters of selected soil properties and the four yield traits.

\begin{tabular}{|c|c|c|c|c|c|c|c|}
\hline Parameters & Semivariogram model & $\mathrm{C}_{0}$ & $c_{0}+c$ & Range (m) & $\mathbf{r}$ & Spatial class & RMSE \\
\hline $\mathrm{C}\left(\mathrm{g} \mathrm{dm}^{-3}\right)$ & Gaussian & 1.16 & 4.23 & $>160$ & 27.4 & $\mathrm{~S} / \mathrm{M}$ & 1.62 \\
\hline $\mathrm{pH}$ & Gaussian & 0.06 & 0.09 & $>285$ & 66.7 & M & 0.02 \\
\hline $\mathrm{S} / \mathrm{m}^{2}\left(\mathrm{no} . \mathrm{m}^{-2}\right)$ & Exponential & 956 & 1436 & 165 & 66.6 & $M$ & 273 \\
\hline G/S (no. spike ${ }^{-1}$ ) & Spherical & 5.85 & 7.80 & 210 & 75.0 & $\mathrm{M} / \mathrm{W}$ & 1.55 \\
\hline MGW (mg) & Exponential & 0.14 & 1.55 & 220 & 9.0 & S & 0.46 \\
\hline GY $\left(\mathrm{Mg} \mathrm{ha}^{-1}\right)$ & Circular & 0.01 & 0.22 & 100 & 4.6 & S & 0.03 \\
\hline
\end{tabular}

$\mathrm{c}_{0}$, nugget variance; $\mathrm{c}_{0}+\mathrm{c}$, sill; r, random variation = nugget/sill(\%); spatial class, class of spatial dependence; RMSE, root mean square error; C, carbon; S, strong; M, moderate; $\mathrm{W}$, weak; $\mathrm{S} / \mathrm{m}^{2}$, no. of spikes per square meter; G/S, no. of grains per spike; MGW, mean grain weight (mg); GY, grain yield per hectare $\left(\mathrm{Mg} \mathrm{ha}^{-1}\right)$. 
A

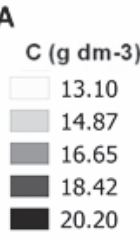

Figure 2. Spatial distribution maps of selected soil traits, obtained by interpolation through inverse distance weighting: A) organic carbon $(\mathrm{C})$; B) $\mathrm{pH}$.

\section{A}

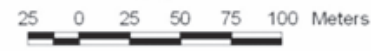

B

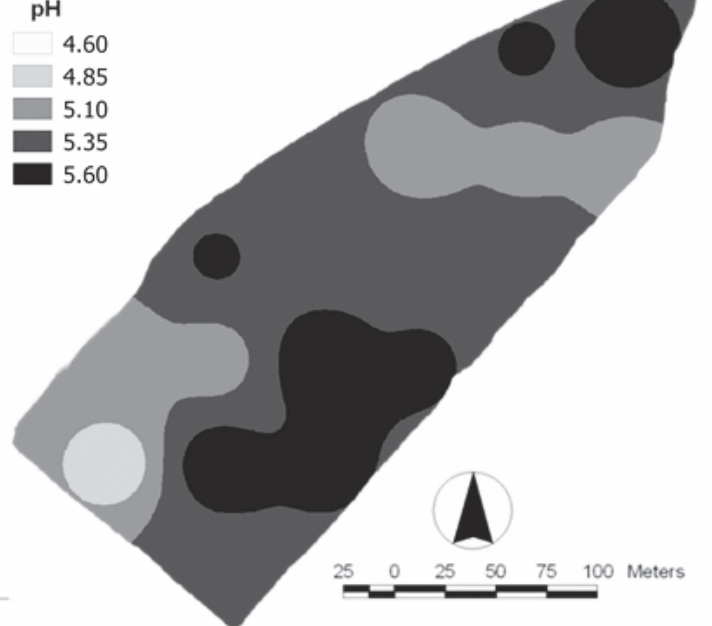

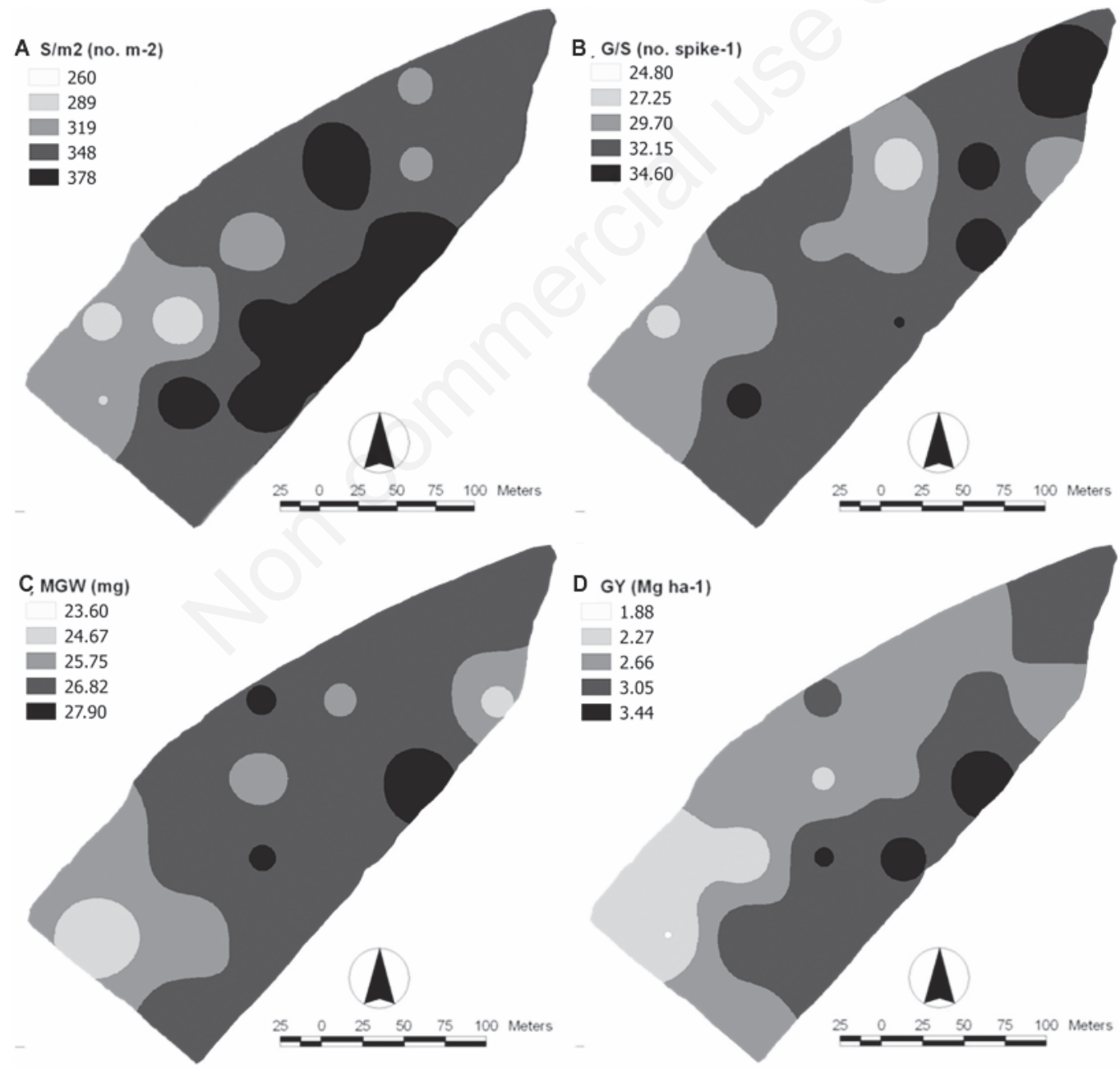

Figure 3. Spatial distribution maps of grain yield parameters, obtained by interpolation through inverse distance weighting: A) spikes per square meter $\left(\mathrm{S} / \mathrm{m}^{2}\right)$; B) grains per spike $(\mathrm{G} / \mathrm{S})$; C) mean grain weight $(\mathrm{MGW})$; D) grain yield $(\mathrm{GY})$. 
GY, spherical for G/S, exponential for $\mathrm{S} / \mathrm{m}^{2}$ and MGW. Root mean square error (RMSE) that was used to describe the goodness of fit of these models, showed a high level only in $\mathrm{S} / \mathrm{m}^{2}$. However, the gap with the other traits could be greatly reduced calculating RMSE as percentage mean value (relative RMSE).

Semivariogram slopes were always positive (data not shown), implying a spatial dependence for all variables. Semivariance increased to a constant value (sill) in GY, G/S and MGW. In the other three variables $\left(\mathrm{C}, \mathrm{pH}\right.$ and $\mathrm{S} / \mathrm{m}^{2}$ ), semivariance increased without reaching a maximum at low lag distance. This means, either that a strict range value might be identified outside the field size, or that the number of samples was insufficient to extrapolate spatial dependence (Cambardella and Karlen, 1999). The spatial dependence for these variables can be evaluated using the sill value at which the semivariogram starts to flatten, or by visual interpretation of nugget significance (Di Virgilio et al., 2007). Based on the thresholds proposed by Cambardella and Karlen (1999), a strong spatial dependence $(\mathrm{r}<25 \%)$ was observed for $\mathrm{GY}$ and MGW; spatial dependence progressively loosened in $\mathrm{C}, \mathrm{pH}$ and $\mathrm{S} / \mathrm{m}^{2}$ $(\mathrm{r}=25-75 \%)$; at last, $\mathrm{G} / \mathrm{S}$ was at the border line for spatial independence ( $r>75 \%)$ (Table 5). The smallest range with a rapidly flattening semivariogram was evidenced in GY, suggesting a patchy distribution for this trait. A non-negligible nugget variance was shown in all variables, as the likely consequence of low trait variability or unaccountable errors in measuring.

Despite useful information from the above-discussed OK parame-

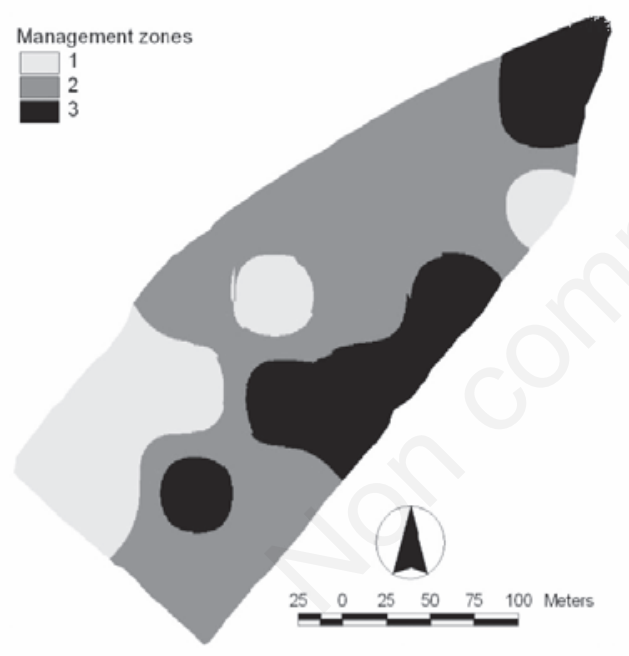

Figure 4. Management zones map in the 4.7 ha wheat field. No. 1, 2 and 3 correspond to low, intermediate and high level, respectively, of the two soil traits and the four yield parameters, in accordance with Table 6. ters, IDW was retained as sounder procedure for interpolating the 18 data points into maps of spatial distribution.

\section{Management zones}

Clustering the 18 data points for the combined $\mathrm{C}$ and $\mathrm{pH}$ led to three clusters of variable size, associated with low (L), intermediate (I) and high $(\mathrm{H})$ level of the two traits (Table 6). The three clusters also featured low, intermediate and high values of crop yield parameters. Especially in the case of GY that epitomises the three yield components, each cluster mean was statistically different, resulting in a $54 \%$ GY difference between the $\mathrm{L}$ and $\mathrm{H}$ level. It is, nevertheless, clear that further years of wheat cropping would be needed to better establish management zones with respect to this one year case study.

Cluster analysis has already been used to sub-divide a field into zones suited for different management, by minimising within-group variation while maximising among-group variation (Stafford et al., 1999; Chang et al., 2014). However, the variable management of crop inputs as $\mathrm{N}$ fertiliser has prevailed in wheat studies (Diacono et al., 2013), over the identification of inherent constraints to wheat production. Moreover, limiting conditions to wheat production have been identified with soils featuring an unfavourable structure (Hakojärvi et al., 2013), also in association with high sodium and pH (Rasouli et al., 2013). To our knowledge, no study before ours has addressed wheat growing on acid lateritic soils under wet, sub-tropical climate. Thus, a vast area of the globe has not received sufficient scientific attention, despite the large deficit in wheat production affecting large countries as Brazil (CONAB, 2014).

The map resulting from $\mathrm{C}$ and $\mathrm{pH}$ clustering depicts three management zones (Figure 4), which are consistent with previous maps of $\mathrm{C}$ and $\mathrm{pH}$, and the four yield parameters (Figures 2 and 3, respectively). The area under management zone 1 (low level) is evidenced in the south-western corner of the field, and in two separate spots. Conversely, the area under management zone 3 (high level) is located along the eastern border, in the north-eastern tip, and a separate spot. The residual area belongs to management zone 2 (intermediate level). The three management zones make up $21.8,54.0$ and $24.2 \%$ of field surface for $\mathrm{L}, \mathrm{I}$ and $\mathrm{H}$, respectively.

Delineating homogeneous zones based on soil attributes subjected to limited temporal variation, as $\mathrm{C}$ and $\mathrm{pH}$, represents a substantial advantage over a delineation based on fluctuating parameters. The former system allows more reliable and effective measures to be deployed for the amelioration of low performing areas. This fosters a strategic approach to crop problems, whereas only tactical decisions may be based on temporally unstable attributes. The identification of soil traits featuring high temporal stability has already been indicated a top priority in homogeneous zone delineation (Casa and Castrignanò, 2008), as premise for successful site-specific management across growing seasons.

Table 6. Average soil carbon, $\mathrm{pH}$ and crop yield parameters in three clusters obtained from the 18 data.

\begin{tabular}{|c|c|c|c|c|c|c|c|}
\hline Cluster & Level & C & $\mathrm{pH}$ & $\mathrm{S} / \mathrm{m}^{2}$ & $\mathrm{G} / \mathrm{S}$ & MGW & GY \\
\hline 1 & $\mathrm{~L}$ & $14.1 \mathrm{~b}$ & $4.92 \mathrm{~b}$ & $294 \mathrm{~b}$ & $27.9 \mathrm{~b}$ & $24.9 \mathrm{~b}$ & $2.05 \mathrm{c}$ \\
\hline 2 & I & $15.3 \mathrm{~b}$ & $5.23 \mathrm{a}$ & $336 \mathrm{a}$ & $30.0 \mathrm{~b}$ & $26.2 \mathrm{a}$ & $2.62 \mathrm{~b}$ \\
\hline 3 & $\mathrm{H}$ & $17.2 \mathrm{a}$ & $5.46 \mathrm{a}$ & $363 \mathrm{a}$ & $32.9 \mathrm{a}$ & $26.5 \mathrm{a}$ & $3.16 \mathrm{a}$ \\
\hline
\end{tabular}

L, I and H mean low, intermediate and high level, respectively; S/m², no. of spikes per square meter; G/S, no. of grains per spike; MGW, mean grain weight (mg); GY, grain yield per hectare (Mg ha ${ }^{-1}$ ). In all traits analysis of variance was statistically significant; different letters indicate significantly different means according to the least significant difference test ( $\mathrm{P} \leq 0.05)$ 


\section{Conclusions}

In this case study, the delineation of management zones was shown a valuable means to identify field areas suffering inherent soil constraints as low $\mathrm{C}$ and $\mathrm{pH}$, although further years would be needed to prove their consistency in influencing the wheat crop. Owing to their relationship with yield, these two traits were largely responsible for the wide gap between low and high yielding zone. Only the high yielding zone attained a grain yield comparable with the world average, on about $25 \%$ of field surface. Thus, the remaining $75 \%$ is suited for amelioration of low soil $\mathrm{C}$ and $\mathrm{pH}$.

The establishment of management zones leads to a concentration of improving efforts in areas potentially most responsive, which is the premise for efficient use of limited and costly resources using precision agriculture techniques. Therefore, delineating management zones was shown an appropriate method to define sub-field areas for a variable application of soil amendments. The geo-statistical approach allowed management zones to be traced while saving in the amount of analysis for soil physical and chemical properties, compared to traditional approaches. This saving is an important premise for diffusing these practices in world areas where limited financial resources hamper investment plans.

Despite only one year of wheat cropping, hindrance to grain yield was associated with consistent soil traits as $\mathrm{C}$ and $\mathrm{pH}$. Thus, their constraint is much likely to repeat in time, avoiding the drawback of low temporal stability that affects all plant, and many soil, parameters.

\section{References}

Bonham-Carter GF, 1994. Geographic Information systems for geoscientists: modelling with GIS. Pergamon, Elsevier, Amsterdam, the Netherlands.

Brady N, Weil R, 2008. The nature and properties of soils. $14^{\text {th }}$ ed. Pearson, New York, NY, USA.

Cambardella CA, Karlen DL, 1999. Spatial analysis of soil fertility parameters. Precis. Agric. 1:5-14.

Casa R, Castrignanò A, 2008. Analysis of spatial relationships between soil and crop variables in a durum wheat field using a multivariate geostatistical approach. Eur. J. Agron. 28:331-42.

Chang D, Zhang J, Zhu L, Ge SH, Li PY, Liu GS, 2014. Delineation of management zones using an active canopy sensor for a tobacco field. Comput. Electron. Agric. 109:172-8.

Chen F, Zhang F, Cheng X, Morris C, Xu H, Dong Z, Zhan K, Cui D, 2010. Association of Puroindoline b-B2 variants with grains traits, yield components and flag leaf size in bread wheat (Triticum aestivum L.) varieties of the Yellow and Huai Valleys of China. J. Cereal Sci. 52:247-53.

CONAB (Companhia Nacional de Abastecimento), 2014. Acompanhamento da safra brasileira - Grãos v. 2. Brasilia (DF), Brasil: Companhia Nacional de Abastecimento. Available from http://www.conab.gov.br

CONAB (Companhia Nacional de Abastecimento), 2004. Manual de adubação e calagem para os estados do Rio Grande do Sul e Santa Catarina. Comissão de Química e Fertilidade do Solo, Núcleo Regional Sul, Porto Alegre, RS, Brazil.

Diacono M, Rubino P, Montemurro F, 2013. Precision nitrogen management of wheat. A review. Agron. Sust. Dev. 33:219-41.

Di Virgilio N, Monti A, Venturi G, 2007. Spatial variability of switchgrass (Panicum virgatum $\mathrm{L}$.) yield as related to soil parameters in a small field. Field Crop. Res. 101:232-9.
EMBRAPA (Empresa Brasileira de Pesquisa Agropecuária), 2006. Sistema brasileiro de classificação de solos. 2nd ed. Empresa Brasileira de Pesquisa Agropecuária, Centro Nacional de Pesquisa de Solos, Rio de Janeiro, RJ, Brazil.

Ehlers W, Köpke U, Hesse F, Böhm W, 1983. Penetration resistance and root growth of oats in tilled and untilled loess soil. Soil Till. Res. 3:261-75.

Evans LT, Fischer RA, 1999. Yield potential: its definition, measurement, and significance. Crop Sci. 39:1544-51.

FAOSTAT, 2015. ProdSTAT: crops. Food and Agriculture Organization of the United Nations, Statistics Division. Available from: http://faostat.fao.org

Fridgen JJ, Kitchen NR, Sudduth KA, Drummond ST, Wiebold WJ, Fraisse CW, 2004. Management zone analyst (MZA): software for subfield management zone delineation. Agron. J. 96:100-8.

Giotto E, Robaina AD, 2007. A agricultura de precisão com o CR Campeiro 7 - Manual do usuário. UFSM/Centro de Ciências Rurais/Departamento de Engenharia Rural/Laboratório de Geomática, Santa Maria, RS, Brazil.

Hakojärvi M, Hautala M, Ristolainen A, Alakukku L, 2013. Yield variation of spring cereals in relation to selected soil physical properties on three clay soil fields. Eur. J. Agron. 49:1-11.

Hartigan JA, Wong MA, 1978. Algorithm as 136: a k-means clustering algorithm. Appl. Stat. 28:100-8.

Jones JB, 2003. Agronomic handbook - management of crops, soils, and their Fertility. CRC Press, Boca Raton, FL, USA.

Machraoui SBM, Errouissi F, Hammouda MB, Nouira S, 2010. Comparative effects of conventional and no-tillage management on some soil properties under Mediterranean semi-arid conditions in northwestern Tunisia. Soil Till. Res. 106:247-53.

Maluf JRT, 2000. A new climatic classification for the State of Rio Grande do Sul, Brazil. Rev. Bras. Agrometeorol. 8:141-50.

Miao Y, Mulla DJ, Robert PC, 2006. Spatial variability of soil properties, corn quality and yield in two Illinois, USA fields: implications for precisions corn management. Precision Agric. 7:5-20.

Miranzadeh H, Emam Y, Seyyed H, Zare S, 2011. Productivity and radiation use efficiency of four dryland wheat cultivars under different levels of nitrogen and chlormequat chloride. J. Agr. Sci. Tech. 13:339-51.

Moreno FR, Lukas V, Neuder L, Dryslova T, 2013. Spatial interpretation of plant parameters in winter wheat. Precision Agric. $33: 219-41$.

Pierce FJ, Nowak P, 1999. Aspects of precision agriculture. Adv. Agron. 67:1-85.

Rasouli F, Pouya AK, Karimian N, 2013. Wheat yield and physicochemical properties of a sodic soil from semi-arid area of Iran as affected by applied gypsum. Geoderma 194:246-55.

Santos HG, Jacomine PKT, Anjos LHC, Oliveira VA, Oliveira JB, Coelho MR, Lumbreras JF, Cunha TJF, 2013. Sistema brasileiro de classificação de solos. $3^{\text {rd }}$ ed. Empresa Brasileira de Pesquisa Agropecuária, Brasília, DF, Brazil.

Santi AL, Amado TJC, Cherubin MR, Martin TN, Pires JL, Flora LPD, Basso CJ, 2012. Análise de componentes principais de atributos químicos e físicos do solo limitantes à produtividade de grãos. Pesq. Agropec. Bras. 47:1346-57.

Singh RP, Trethowan R, 2007. Breeding spring bread wheat for irrigated and rainfed production systems of the developing world. In: M.S. Kang, P.M. Priyadarshan (Eds.), Breeding major food staples. Blackwell, Ames, IA, USA, pp 109-40.

Stafford JV, Lark RM, Bolam HC, 1999. Using yield maps to regionalize fields into potential management units. In: P.C. Robert, R.H. Rust, W.E. Larson (Eds.), Precision agriculture. ASA, CSSA, \& SSSA, Madison, WI, USA, pp 225-37. 
Suzuki LEAS, Reinert DJ, Reichert JM, Lima CLR, 2008. Estimativa da susceptibilidade à compactação e do suporte de carga do solo com base em propriedades físicas de solos do rio grande do sul. Rev. Bras. Ci. Solo 32:963-73.

Taylor HM, Robertson GM, Parker JJ, 1966. Soil strength root penetration relations for medium to coarse textured soil materials. Soil Sci. 102:18-22.
Tedesco MJ, Gianello C, Bissani CA, Bohnen H, Volkweiss SJ, 1995. Analíses do solo, plantas e outros materiais. Boletim Técnico no. 5 Departamento de Solos, Facultade de Agronomia, Universidade Federal do Rio Grande do Sul, Porto Alegre, RS, Brazil.

Zanon AJ, Streck NA, Rosa HT, Walter LC, Alberto CM, 2012. Número de folhas associado com duplo anel e espigueta terminal em cultivares de trigo. Rev. Ciênc. Agron. 43:569-78. 